\title{
Perception of Organizational Politics, Psychological Safety, and Work Efforts of Senior High School Teachers
}

\author{
Lebbaeus Asamani, PhD, Senior Lecturer \\ Bakari Yusuf Dramanu, PhD, Senior Lecturer \\ Emilyn Ofosu-Amaah, PhD Student
}

Department of Education and Psychology, College of Education Studies,

University of Cape Coast, Cape Coast-Ghana

Doi:10.19044/esj.2020.v16n19p195 URL:http://dx.doi.org/10.19044/esj.2020.v16n19p195

\begin{abstract}
Politics is a phenomenon that can be experienced wherever there are more than two people present, and schools or work organizations are no exceptions. This paper focuses on investigating the extent to which Ghanaian Senior High School teachers' perceptions of organizational politics and psychological safety relate to each other, and how it influences the teachers' work efforts. A cross-sectional research design was used, which involves 275 teachers conveniently sampled from public senior high schools in the Tamale Municipality of Ghana. Standardized self-report questionnaires were adapted to collect the data, and it was analyzed using standard multiple linear regression. The results indicated that perception of organizational politics is a significant predictor of self-report work efforts of Senior High School teachers, but psychological safety was not. The results further showed that all the three dimensions of politics perception measured in the study significantly predict work efforts. This is with general political behaviour being the most significant predictor. Curiously, psychological safety perception had a significant positive relationship with politics perception. The findings from the current study suggest that perception of workplace politics is a critical determinant of attitude and behaviour of individuals at work, including work efforts. Among others, the paper recommends that pragmatic measures must be put in place to minimize workplace politics and perception of same in order to enhance work efforts in the workplace.
\end{abstract}

Keywords: Organizational politics perception, psychological safety, work efforts, general political behavior 


\section{Introduction}

Politics is a phenomenon that can be experienced wherever there are more than two people present, and schools or work organizations are no exceptions. Since work organizations including schools comprise of people from different backgrounds, with different approaches of conducting their day to day activities within the organization, there may exist some form of strain or what has been frequently referred to as organizational politics. This phenomenon has been found to significantly affect the intentions, pursuit of work goals, conduct, and emotional well-being of employees and how individuals advance within the organization (Gandz \& Murray, 1980; Madison, Allen, Renwick \& Mayes, 1980). Brandon and Seldman (2004) viewed organizational politics as informal, unofficial, and sometimes behindthe-scenes efforts to sell ideas, influence an organization, increase power, or achieve other targeted objectives. Bodla and Danish (2009) also argued that organizational politics involves aspects of organizational life and it relates to power, authority, and influence.

Although organizational politics are generally portrayed negatively, organizational politics are not inherently bad. It is therefore important to be aware of the potentially destructive aspects of organizational politics in order to minimize their negative effect. Vigoda (2002) observed that organizational politics may be advantageous or beneficial to organizations and other stakeholders. Also, it may have positive outcomes such as career advancement, recognition and status, and enhanced sense of control. Vigoda, however, cautioned that if politics is perceived to be high within the organization, the commitment level of employees might be affected. Even though perceptions of organizational politics are inevitable realities, they can be managed and controlled within the organization. However, if not managed and controlled to a minimum level, it can lead to organizational discomfort (feeling unsafe psychologically) and also results to low level of employees' commitment and work efforts.

Extant literature suggests that the political environment at work has enormous effect on the behaviour and attitudes of individuals in different ways ranging from extremely beneficial to enormously harmful (Gandz \& Murray, 1980; Hochwarter et al., 2003; Ferris et al., 2002; Bodla et al., 2014). Dhar (2009) added that the importance of organizational politics lies in its potential consequences and effect on work outcomes. At the hub of educational outcomes is the teacher who is the heart of classroom instruction (Nyambui, 2016).

At the secondary school level in public schools in Ghana, teachers have a great deal of job security once they are employed. The remuneration of teachers is among the lowest in the country. This might be due to the fact that there is high rate of supply of graduate teachers and most people see teaching 
as a "stepping stone" or temporary job, though they have been trained as teachers. Thus, teaching is not seen as a prestigious profession and teachers largely lack the commitment and dedication to the service required to deliver quality education. Generally, the lack of interest in the teaching profession created a situation where there is high attrition rate, which also creates ready vacancies for the newly strained to be posted.

The appointment of a teacher may only be terminated when he or she is engaged in gross misconduct. Since there is a high unemployment rate and lack of employment opportunities in other sectors, teachers reluctantly remain in the teaching profession, not because they want to, but due to circumstances. Therefore, this may affect the efforts that teachers put into their work. This may also become worse if they perceive unfair treatments from their heads and unequal access to opportunities in their schools. Senior High School teachers in Ghana are mostly bachelor's and master's degree holders. These categories of teachers belong to the Ghana National Association of Graduate Teachers (NAGRAT) which fights for the social and economic protection of members. This helps to protect the jobs of teachers to a great extent.

Rosen et al. (2006) postulated that the perception of politics is related to work efforts through employees' perception of social exchange relationships. Similarly, the potential predicting role of psychological safety perception through social exchange relationship was postulated by Bodla et al. (2014). Between these two variables, one may relate strongly to work effort of teachers than the other. The presented study investigated the extent to which perception of organizational politics and psychological safety relate to the work effort of secondary school teachers.

\subsection{Perception of Organizational Politics, Psychological Safety, and Work Efforts}

Theory and research in organizational politics have been categorized into political behaviour and its effects, and the nature of organizational politics perceptions (Ferris, Adams, Kolodinsky, Hochwarter \& Ammeter, 2002). However, these two have been conceived generally as independent. The first aspect of political behaviour involves the nature of actual political behaviour, types of tactics and strategies, and their consequences on organizational outcomes. The second category focuses on perceptions of politics in work environments by individual employees, the antecedents of such perceptions, and their consequences. Research interest in perceptions of organizational politics emerged with Gandz and Murray (1980) who suggested that politics should be conceived as a subjective evaluation rather than an objective reality. Again, it has been noted that individuals respond on the basis of their perceptions of reality, not necessarily reality per se (Lewin, 1936). Porter (1976) argued that perceptions of politics are important to investigate 
even if they reflect misperceptions of actual events. This made the perceptions aspect of organizational politics emerge as an independent area in social science research.

Researchers indicated that perceptions of organizational politics are often the variable of interest, rather than actual organizational political actions and activities (Lewin, 1936; Porter, 1976; Gandz \& Murray, 1980; Ferris, Russ \& Fandt, 1989). Ferris et al., for instance, emphasized that "organizational politics is a subjective perception, but not necessarily an objective reality" ( $p$. 157). This is because even if the perception of political influence on organizational activities and decision-making processes by an employee is a misrepresentation of actual events, that perception is part of the individual's view of reality. This perception therefore would influence the employee's related cognitive and behavioral responses (Lewin, 1936; Porter, 1976). The perception of organizational politics among secondary school teachers is therefore the focus of the current study.

Ferris, Harrell-Cook, and Dulebohn (2000) noted that perceptions of organizational politics "involves an individual's attribution to behaviors of self-serving intent, and is defined as an individual's subjective evaluation about the extent to which the work environment is characterized by co-workers and supervisors who demonstrate such self-serving behaviour" (p. 90). Gallagher and Laird (2008) also described perceived organizational politics as an individual's view which is normally characterized by colleagues and supervisors demonstrating behaviors that are self-serving. This suggests that perceptions of politics involve an attribution of intent regarding the behaviour of other organizational members which are interpreted as self-serving actions engaged in by others. These perceptions represent subjective evaluations and feelings of employees regarding political behaviour in the work environment.

DuBRJN (1991) posited that the political environment of the workplace is so pervasive that it affects everyone in the organization and that the nature of behaviour of employees is frequently considered as political. Organizational politics perception has been found to have negative relationship with job satisfaction (Kacmar, Bozeman, Carlson \& Anthony, 1999), organizational commitment (Maslyn \& Fedor, 1998), and also the job performance of employees (Anderson, 1994). Folger, Konovsky and Cropanzano (1992) averred that the negative consequences of perceptions of organizational politics arise as a result of employees feeling that they are working in an unjust and unfair environment, which leads to dissatisfaction.

Lencioni (2006) argued that contemporary work environment requires competences in handling conflicting agendas and shifting power bases in order to succeed. The efforts of teachers to accomplish or execute a given task or their ability to combine skills and the right behaviour towards the achievement 
of organizational goals and objectives could be affected by their perception of politics in their schools.

Teachers' work effort in this study refers to the amount of physical and psychological attempts they make in the performance of their duties at a particular time in the school system in order to promote teaching and learning. This also involves the ability of teachers to combine relevant inputs for the enhancement of the teaching and learning processes (Akinyemi, 1993; Okeniyi, 1995). Given that perceptions in general, and perceptions of workplace politics are critical factors of the behaviour and work output of individuals, the work effort of teachers is postulated in this study to be influenced by their perceptions of politics in their schools. Perception of the work environment as highly political may make employees uncomfortable because they may feel that they are working in an unjust and unfair workplace, where efforts and competence might not be rewarded (Folger, Konovsky \& Kropanzano, 1992). Employees in highly political work environment may feel efforts may not be reciprocated in terms of rewards. This would engender more self-serving effort which would lead to disharmony and poor social exchange relationship. This, in turn, may affect their commitment and efforts which they invest into their work.

The second predictor considered in this study, psychological safety perception, represents the perceptions of individuals regarding the consequences of interpersonal risks in their work environment (Edmondson, 2003). Kahn (1990) also described psychological safety as "feeling able to show and employ one's self without fear of negative consequences to selfimage, status, or career" (p. 708). Kahn further suggests that psychological safety shapes how people take charge of their roles in the organization. Thus, in the school environment, if the teachers have a sense of being psychologically safe, they are more likely to perceive less politics and be involved and put more effort into their work.

In this study, psychological safety is conceptualized as a predictor variable of work efforts of teachers. Meanwhile, Vigoda-Gadot (2007) found perception of organizational politics to have moderately mediated the effect of leader in-role behaviour and organizational citizenship behaviour. Social exchange relationship and leader in-role behaviour are conceptually related and could affect the psychological safety perceptions of employees. Schein (1985) argued that psychological safety helps individuals overcome the defensiveness, or "learning anxiety," that occurs when they are presented with data that disconfirm their expectations or hopes, which can thwart productive behaviour. Edmondson (2003) noted that: 
Psychological safety does not imply a cosy environment in which people are necessarily close friends, nor does it suggest an absence of pressure or problems. Rather, it describes a climate in which the focus can be on productive discussion that enables early prevention of problems and accomplishment of shared goals, because people are less likely to focus on self-protection (p. 6).

Psychological safety perception may also have some bearing on perception of organizational politics and vice versa. In an environment of less perception of corporate politics, employees may have a sense of support which could promote psychological safety (Edmondson, 2003). This gives a sense of fair access to resources and information. Also, this is likely to reduce feelings of insecurity and defensiveness among work colleagues. Furthermore, feelings of being psychologically safe make giving and receiving of feedback effective and these promote organizational learning (Schön, 1983) and enhanced performance of employees (Ashford \& Tsui, 1991). Edmondson argued that, similar to help-seeking, feedback-seeking is very important in successful task completion, and carries similar interpersonal risk. Requests for feedback from other team members or other groups place the seekers in a vulnerable situation, where they are likely to hear negative criticism. Psychological safety enables employees to speak up about issues and work challenges directly without any fear of negative consequences. In this case, employees focus on the benefits of expressing their views and seeking information more than negative outcomes of such actions (e.g., the potential embarrassment) for the speaker (Edmondson, 2003).

The literature demonstrates clearly that employees' perceptions of politics at the workplace may have both positive and negative consequences for individual organizational members and the entire organization. One way through which the perception of politics would affect organizational outcomes is through employees' sense of psychological safety. As discussed above, the feeling of psychological safety provides some form of psychological resource for employees to be immersed in their work. Thus, if the teachers perceive high levels of politics in their schools, they may likely feel less secured and distressed, which in turn would affect their teaching activities.

\subsection{Statement of the Problem}

Pertinent literature suggests that the perceptions of organizational politics research largely focused on its negative effects on work outcomes (Kacmar, Bozeman, Carlson \& Anthony, 1999; Maslyn \& Fedor, 1998; Ferris, et al., 2002), and mostly examined direct relationship. There is a dearth of research efforts trying to identify the psychological mechanisms 
that explain how the perceptions engender the negative individual and organizational outcomes. Thus, it is important to investigate the psychological mechanism of the consequences (negative or positive) of perceived organizational politics. To that end, the extent of politics perceived in the Senior High School environment is postulated to have an effect on feeling of psychological safety among teachers and it affects their work efforts. Thus, the work effort of secondary school teachers was expected to be affected by the perceptions of politics and psychological safety.

Ogungbamila (2013) posited that "the negative consequences of organizational politics are 'loss of strategic power, negative feelings (and actions) toward others" (p.128). However, other researchers have found no relationship between perceived organizational politics and employee commitment to their work and the organization (Cropanzano, Howes, Crandey $\&$ Toth, 1997). This suggests that research findings regarding the effects of perception of organizational politics and work or organizational outcomes are not conclusive and conflicting. Furthermore, Bodla, Afza and Danish (2014) noted that most of the researches in this area focused on bivariate relationships between perception of workplace politics and employee or organizational outcomes, not exploring the mechanisms or processes through which the relationships take place.

The processes through which the perceptions operate are critical to the understanding of how it influences attitudes, behavior, and work outcomes (Bodla et al., 2014). Therefore, there have been calls for continuing research to help broaden the understanding of the outcome of organizational politics (e.g. Poon, 2003, 2006; Bodla et al., 2014). Bolden et al., for instance, found a mediating effect of social exchange on the effect of perception of organizational politics on the performance of employees drawn from diverse work settings at national level in Pakistan. Quality social exchange among employees and between employees and management has the potential to promote the feeling of psychological safety among employees.

\subsection{Research Hypotheses}

The current study investigated the direct and indirect effects perceptions of organizational politics on Senior High School teachers' work efforts with psychological safety as a mediating variable. The following research hypotheses have been formulated based on the pertinent literature and the purpose of the study:

$\mathrm{H}_{1}$ : Psychological Safety will have a statistically significant relationship with work effort of Senior High School teachers.

$\mathrm{H}_{2}$ : Perception of politics will have a statistically significant relationship with work effort of Senior High School teachers. 
$\mathrm{H}_{3}$ : Psychological safety and politics perceptions of Senior High School teachers will be positively related.

$\mathrm{H}_{4}$ : Perception of politics will be a better predictor of work effort of Senior High School teachers than their psychological safety.

Consequently, Figure 1 presents the hypothesized model of the paper. Perceptions of organizational politics and psychological safety have been hypothesized as predictors of work efforts of teachers. Also, some form of relationship between psychological safety and perception of organizational politics was postulated as presented in the hypotheses above.

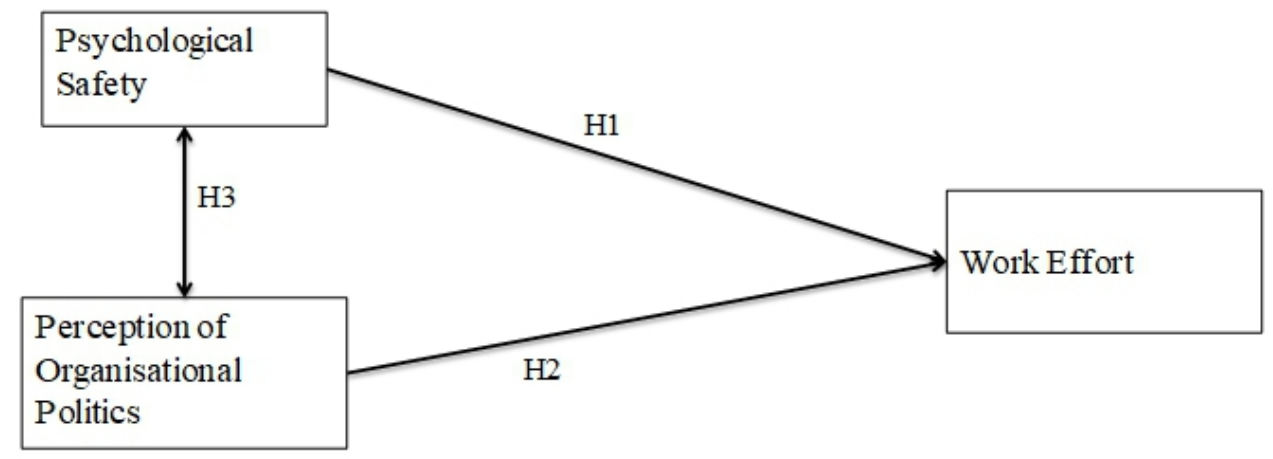

Figure 1. Hypothesized conceptual framework of the study

\section{Research Methodology}

\subsection{Research Design}

The design for the present study is a cross-sectional study of teachers in public senior high schools in the Tamale Municipality of Ghana.

\subsection{Population}

The study area, Tamale Metropolis, in the Northern region of Ghana, has seven public senior high schools. The total number of teachers in the seven school was 561 (Education Management Information System, EMIS, 2018), comprising of 462 males and 98 females.

\subsection{Sample and Sampling Procedure}

All the seven public Senior High School in the Tamale Metropolis were involved in the study. The GPower a-priori sample size determination approach was used to determine the appropriate and adequate sample size for the study. Given $\alpha=.05$, statistical power of .95 , expected effect size of .35 and with at most three predictors in the regression model, the recommended sample size to obtain the expected effect and statistical power is 54. However, the sample was increased to make it more representative. All the female teachers were targeted to be part of the study, but 83 consented to participate. For the male teachers, a systematic random sampling procedure was used to 
sample 255, but 248 gave their consent to participate in the study. Thus, a total of 331 questionnaires were distributed, out of which 275 fully completed questionnaires were obtained from the teachers (return rate of $83.01 \%$ ). Twelve (12) of the cases were later excluded after screening for influential cases, leaving 263 for the final analysis. The net sample used for the final analysis comprised of 197 males (74.9\%) and 66 females (25.1\%).

The average age of the respondents was 39 years, with 13 years average teaching experience. All the teachers had at least First (Bachelor's) degree, and most were married, while others were divorced/widowed (see Table 1).

Table 1. Demographic Characteristics of Respondents $(N=263)$

\begin{tabular}{lclr}
\hline Educational Level & Percent & Marital Status & Percent \\
\hline First degree & 75 & Married & 75 \\
Master's degree & 24 & Never married & 22 \\
Others & 1 & Divorced/Widowed & 3 \\
\hline
\end{tabular}

\section{$2.4 \quad$ Research Instrument}

\subsubsection{Perception of Organizational Politics}

The 12-item three-dimensional perception of organizational politics scale (Kacmar \& Ferris, 1991) was adapted for this study. The three dimensions are General political behaviour, Go long to get along, and Pay and promotion policies. This scale has been found to have good reported reliability of .87 and above (e.g. Kacmar \& Ferris, 1991; Vigoda, 2000). Respondents were asked to rate the extent to which they agreed or disagreed with the items on a five-point Likert type of scale which ranges from 1 (strongly disagree) to 5 (strongly agree). Sample items are: I have seen changes made in policies in this school that only serve the purpose of a few individuals, not for the school; When it comes to pay raise and perception decisions, policies are irrelevant. Higher score on the scale depicts higher perception of organizational politics. The reliability coefficient obtained for this scale in the present study was .83 .

\subsubsection{Psychological Safety Scale}

The six-item psychological safety scale of Edmondson and Wooley (2003) was adapted to measure teachers' perception of psychological safety in their schools. The scale is uni-dimensional and was rated on five-point Likert type of scale which ranges from 1 (strongly disagree) to 5 (strongly agree). Three items are reversed-scored, and previous studies indicate good reliability coefficients for the scale. A sample item is: It is difficult to ask others in this school for help. Bresman and Zellmer-Bruhn (2013) reported a reliability coefficient of .87 , and .89 was obtained in the present study. 


\subsubsection{Work Efforts Scale}

Work effort in this study was measured with self-report threecomponent work effort scale (De Cooman, De Gieter, Pepermans, Jegers, \& Van Acker, 2009). The three dimensions of the scale are: persistence, direction, and intensity. The scale consists of 10 items, scored on a 5-point Likert type of scale which ranges from 1 (strongly disagree) to 5 (strongly agree). Teachers reported the extent to which they persist in the discharge of their duties. This dimension consists of 3 items (e.g., I do not give up quickly when something does not go well at work as a teacher). The other two dimension are direction with 3 items (e.g., When I start an assignment in school, I pursue it to the end), and intensity with 4 items (e.g., I put a lot of energy into any tasks that I commence in the school). The scale has been found to be very reliable in previous studies. For instance, Vantilborgh, Bidee, Willems, Huybrechts and Jegers (2014) had a reliability coefficient of .89. In the present study, a reliability coefficient of .82 was obtained.

\subsubsection{Pilot Testing of Research Instruments}

Three standardized scales were adapted for the present study and were pilot tested with a sample of 43 teachers, comprising of 27 males and 16 females in Upper West Region (a region next to the northern region where the study was conducted) to ensure that the wording of the items were appropriate for the school environment and the Ghanaian context. These are the perception of organizational politics scale (Kacmar \& Ferris, 1991): psychological safety scale (Edmondson \& Wooley, 2003) and the work efforts scale (De Cooman, De Gieter, Pepermans, Jegers, \& Van Acker, 2009).

Minor modifications were made to the original wordings of the items to reflect the school settings. For instance, the word "organization" was replaced with "school" in some cases before the pilot testing was done. All the scales and their subscales showed good psychometric properties and were deemed appropriate and reliable for the current study. The Cronbach's alpha reliability was used for all scale and the coefficients obtained were: .79 for perception of organizational politics, .86 for psychological safety, and .76 for the work efforts scale. All the scales were deemed acceptable for the present study as the coefficients were higher than the often-cited acceptable level of .70 (George \& James, 1993).

\subsection{Data Collection Procedures}

A set of questionnaires was given to teachers who had consented to take part in the study after obtaining approval from the heads of the schools. The purpose of the study was explained to the teachers individually and they were assured of confidentiality of the data. Respondents were not required to write their names on the questionnaires, and there was no attempt to identify 
individual respondents. The questionnaires were numbered for coding purposes. This means there was no threat to the safety of any respondent in the study. Teachers who were free at the time of the distribution completed their questionnaires and were taken immediately they had finished. It took between 25 to 35 minutes to complete a set of questionnaires.

\subsection{Results}

The data was analyzed using both descriptive and inferential statistics. The results are presented using hypotheses, followed by the discussions of the findings. The data were screened and important assumptions regarding particular type of statistical tools were tested. Linear regression analysis assumptions such as adequacy of sample size, linear relationships between predictors and criterion variables, independence of errors, multicollinearity and non-skewness of measures were all satisfied. Table 2 shows the descriptive statistics of the scale measures in the study.

Table 2. Means, Standard Deviations, Skewness and Kurtosis of study Variables

\begin{tabular}{lccll}
\hline Variables & Mean & S. D. & Skewness & Kurtosis \\
\hline $\begin{array}{l}\text { Perception of organizational } \\
\text { politics }\end{array}$ & 32.67 & 10.93 & -.198 & -.039 \\
$\begin{array}{l}\text { Work effort } \\
\text { Psychological Safety }\end{array}$ & 51.45 & 7.78 & -.803 & -.300 \\
\hline S.D & 19.84 & 4.96 & -.091 & -.728 \\
\hline
\end{tabular}

S.D. $=$ standard deviation

$H_{1}$ : Psychological Safety will have significant positive relationship with work effort.

$\mathrm{H}_{2}$ : Psychological safety will relate negatively with perception of politics

$H_{3}$ : Perception of organizational politics will relate negatively with work effort

The Pearson's Product Moment correlation coefficient was used to find out the nature of relationships between the variables. The result showed no significant relationship between psychological safety and work efforts $(\mathrm{r}=$ $-.035, \mathrm{p}>.05)$ and a significant positive relationship between psychological safety and perception of politics $(r=.276, \mathrm{p}<.01)$ of secondary school teachers. Perception of politics is also negatively related with work efforts ( $\mathrm{r}$ $=-.466, \mathrm{p}<.01$ ). Thus, perception of organizational politics had a significant relationship with work effort, but psychological safety perception did not. There was also a positive relationship between perception of organizational politics and psychological safety perception. Figures 2 and 3 present the scatter plots with the lines of best fit. 
Table 3. Pearson's Product Moment Correlation Coefficients between perceptions of organizational politics, psychological safety, and work effort

\begin{tabular}{llll}
\hline & Work Effort & POP & Psych Safety \\
\hline Work Effort & 1.000 & \\
POP & $-.466^{* *}$ & 1.000 & \\
Psychological Safety & -.035 & $.276^{* *}$ & 1.000 \\
\hline \multicolumn{2}{r}{ Significant at .01} & \multicolumn{2}{r}{ POP = perception of organisational politics }
\end{tabular}

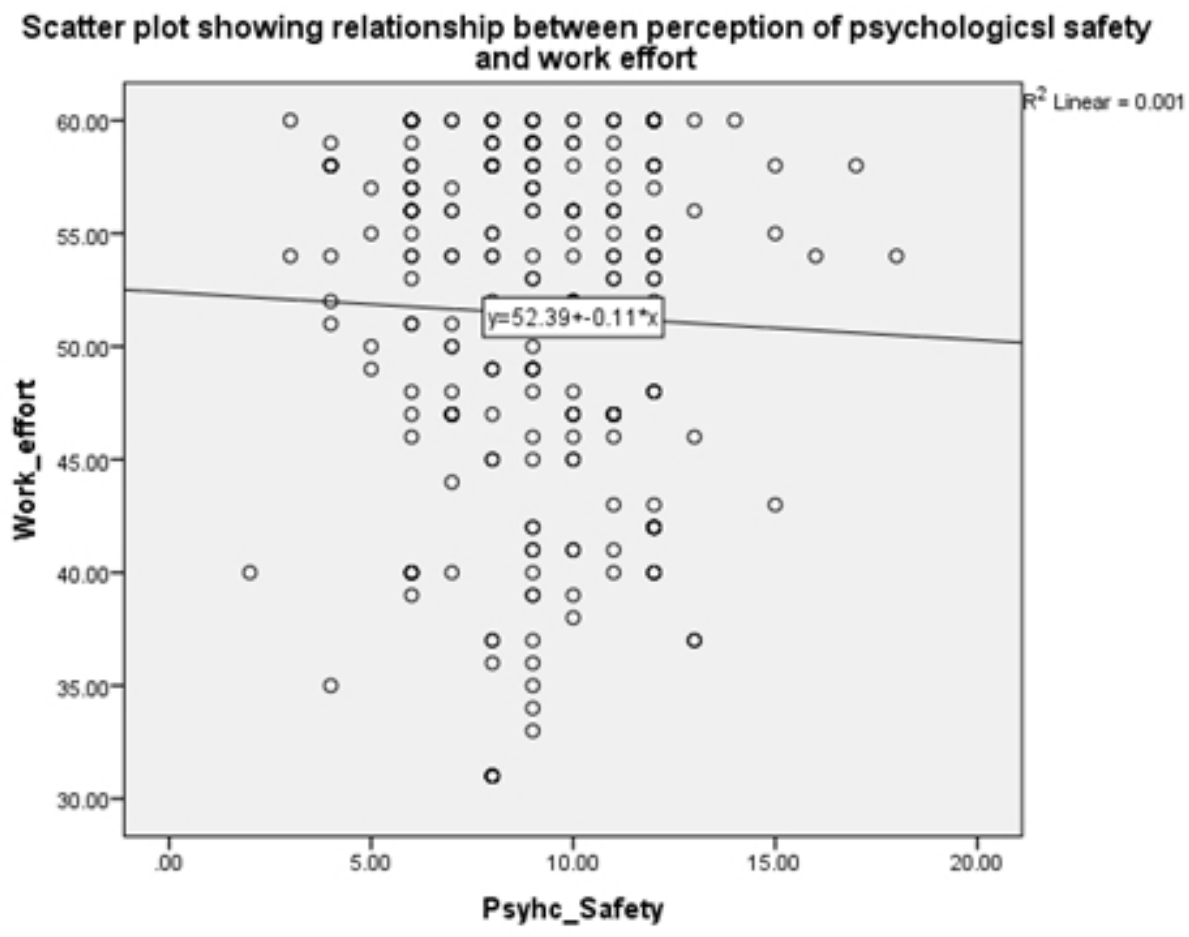

Figure 2. Scatter plot showing relationship between perception of psychological safety and work effort 


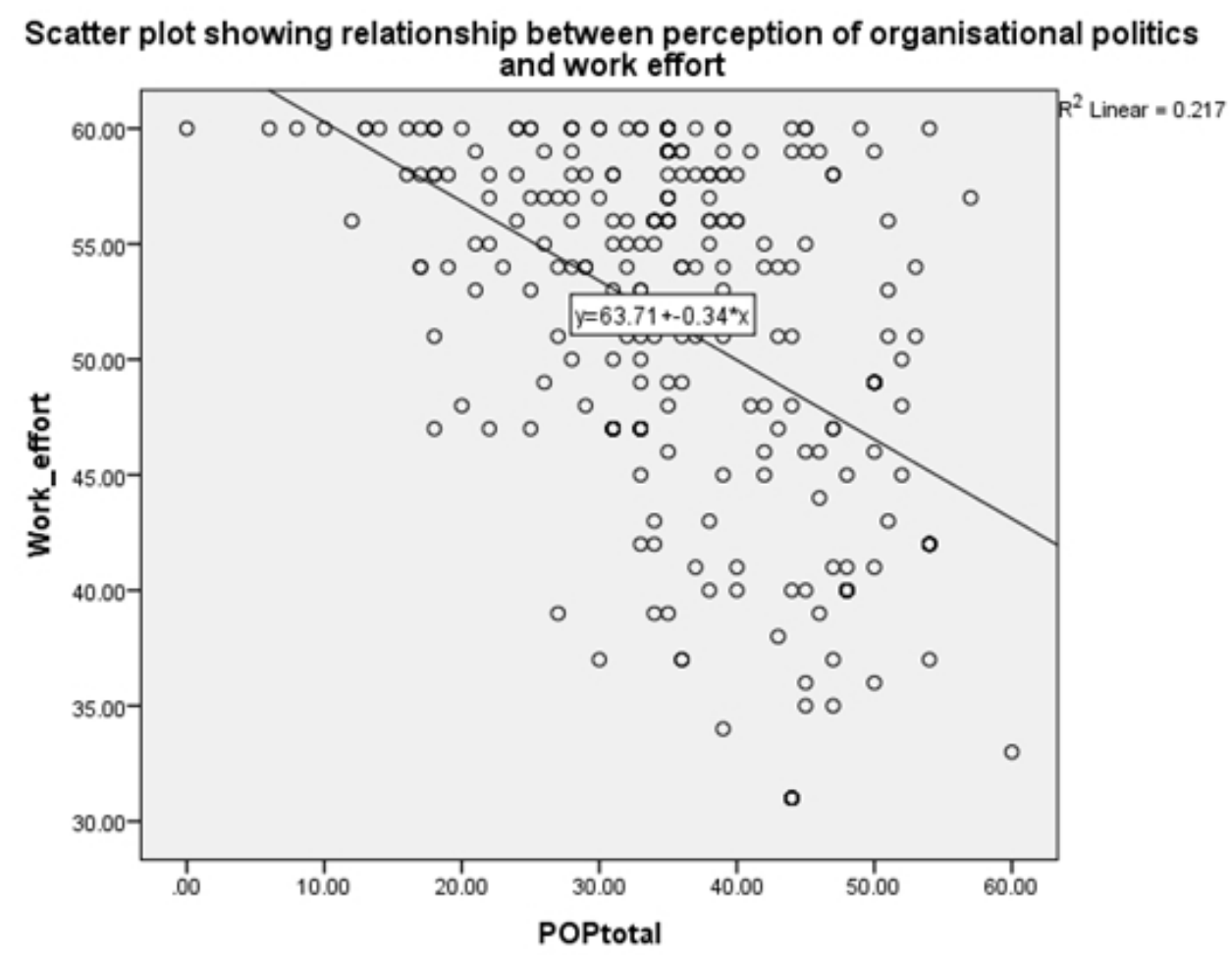

Figure 3. Scatter plot showing the relationship between perception of organisational politics and work effort

Subsequently, the relationships between psychological safety and the dimensions of perception of politics were considered. Thus, the results indicated that only general political behaviour is significantly related with psychological safety $(\mathrm{r}=.334, \mathrm{p}<.001)$. Thus, general political behaviour related positively with perception of the teachers' feeling of being safe at work, but go ahead behaviour and perceptions of pay and promotions did not relate to the feeling of psychological safety.

Table 4. Correlation Coefficients between Psychological Safety and Dimensions of Perception of Politics

\begin{tabular}{lllll}
\hline Dimensions & Psych Safety & Gen PB & Go Ahead & Pay Promotions \\
Psych Safety & 1 & & & \\
Gen. PB & $.334^{* *}$ & 1 & & \\
Go Ahead & -.043 & -.027 & 1 & 1 \\
Pay Promotions & .042 & $.189^{* *}$ & $.141^{*}$ & 1 \\
\hline en PB = General political behaviour & & Psych safety = Psychological safety \\
Significant at .05; **significant at .01 & & &
\end{tabular}

$H_{4}$ : Perception of (a) organizational politics and (b) psychological safety will significantly predict work effort of Senior High School teachers 
Hypothesis 4 was tested with standard linear multiple regression analysis, including psychological safety in the model since it is significantly related with perception of politics. The regression analysis (Table 5) indicated that perception of organizational politics and psychological safety accounted for $22.6 \%$ of the variance in the work efforts of the teachers. The model was significant $\left(\mathrm{R}=.476, \mathrm{R}^{2}=.226, \mathrm{~F}_{(2,260)}=38.061, \mathrm{p}<.001\right)$, which means that the psychological safety and perception of organizational politics were important in predicting work efforts of Senior High School teachers.

Table 5. Standard multiple regression results of work efforts on perception of politics and psychological safety

\begin{tabular}{|c|c|c|c|c|c|c|c|c|c|c|c|}
\hline \multirow{2}{*}{\multicolumn{2}{|c|}{ Model }} & \multicolumn{2}{|c|}{$\begin{array}{l}\text { Unstandardized } \\
\text { Coefficients }\end{array}$} & \multirow{2}{*}{$\begin{array}{l}\text { Standardized } \\
\text { Coefficients } \\
\text { Beta }\end{array}$} & \multirow[t]{2}{*}{$\mathrm{T}$} & \multirow[t]{2}{*}{ Sig. } & \multicolumn{3}{|c|}{ Correlations } & \multicolumn{2}{|c|}{$\begin{array}{l}\text { Collinearity } \\
\text { Statistics }\end{array}$} \\
\hline & & B & $\begin{array}{l}\text { Std. } \\
\text { Error }\end{array}$ & & & & $\begin{array}{l}\text { Zero- } \\
\text { order }\end{array}$ & Partial & Part & Tolerance & VIF \\
\hline \multirow{3}{*}{1} & (Constant) & $\begin{array}{l}61.73 \\
0\end{array}$ & 1.862 & & 33.16 & .000 & & & & & \\
\hline & $\begin{array}{l}\text { Psych } \\
\text { Safety }\end{array}$ & .304 & .170 & .101 & 1.79 & .075 & -.035 & .110 & .097 & .924 & 1.083 \\
\hline & POP total & -.364 & .042 & -.494 & -8.70 & .000 & -.466 & -.475 & -.475 & .924 & 1.083 \\
\hline
\end{tabular}

The results presented in Table 5 indicate that perception of organizational politics was significant in predicting work efforts of the teachers $(\beta=-.494, \mathrm{p}<.001)$, but psychological safety was not $(\beta=.101, \mathrm{p}$ $=.075)$. Also, there was a negative relationship between perception of organizational politics and work efforts of secondary school teachers. Perception of politics accounted for $22.56 \%$ of the variance (the square of the part correlation) in work effort of the teachers, after controlling psychological safety.

The regression equation for the model, using the unstandardized coefficient, therefore is:

Work effort $=61.73-.364($ POP $)$

Perception of organizational politics was partitioned into the three dimensions, general political behaviour, go ahead and pay and promotion, to find out which of the dimensions predicted work efforts of the teachers most (see Table 6). The three dimensions together accounted for $22.1 \%$ of the variance in work efforts $\left(\mathrm{R}=.470, \mathrm{R}^{2}=.221\right.$, adj. $\mathrm{R}^{2}=.212, \mathrm{~F}_{(3,259)}=24.48$, $\mathrm{p}<.001)$. All the three dimensions significantly predicted work efforts, with general political behaviour being the most significant predictor $(\beta=-.400, p<$ $.001)$. Pay and promotions was the second best predictor $(\beta=-.151, \mathrm{p}=.008)$ and go ahead the least predictor $(\beta=-.115, \mathrm{p}=.039)$. The regression equation for predicting work effort through the dimensions of perception of organizational politics is as follows: 
Work effort $=62.92-.35$ (Gen. PB) -.23 (Go ahead) -.44 (pay and promotion)

Table 6. Standard Multiple Regression results of Dimensions of Politics Perception and Work Efforts

\begin{tabular}{|c|c|c|c|c|c|c|c|c|c|c|c|}
\hline \multirow{2}{*}{\multicolumn{2}{|c|}{ Model }} & \multicolumn{2}{|c|}{$\begin{array}{l}\text { Unstandardized } \\
\text { Coefficients }\end{array}$} & \multirow{2}{*}{$\begin{array}{l}\text { Standardized } \\
\text { Coefficients } \\
\text { Beta }\end{array}$} & \multirow[t]{2}{*}{$\mathrm{T}$} & \multirow[t]{2}{*}{ Sig. } & \multicolumn{3}{|c|}{ Correlations } & \multicolumn{2}{|c|}{$\begin{array}{l}\text { Collinearity } \\
\text { Statistics }\end{array}$} \\
\hline & & B & $\begin{array}{l}\text { Std. } \\
\text { Error }\end{array}$ & & & & $\begin{array}{l}\text { Zero- } \\
\text { order }\end{array}$ & Partial & Part & Tole'ce & VIF \\
\hline \multirow{5}{*}{1} & (Constant) & 62.920 & 1.852 & & 33.980 & .000 & & & & & \\
\hline & Gen. PB $^{*}$ & -.350 & .049 & -.400 & -7.144 & .000 & -.425 & -.406 & -.392 & 961 & 1.040 \\
\hline & Go Ahead & -.230 & .111 & -.115 & -2.074 & .039 & -.125 & -.128 & -.114 & .977 & 1.023 \\
\hline & Pay & -.438 & .164 & -.151 & -2.673 & .008 & -.243 & -.164 & -.147 & .943 & 1.060 \\
\hline & Promotions & & & & & & & & & & \\
\hline
\end{tabular}

*Gen. PB = General political behaviour

\subsection{Discussion of Findings}

Workplace politics is said to be pervasive and unavoidable in organizations. Even though most studies indicated that it has a negative effect on workplace behaviour and outcomes, some studies suggest that it has positive aspects such as opportunity generation in some situations (Hochwarter, Kacmar, Perrewé \& Johnson, 2003).

The results of this study indicated that perception of politics by the teachers had a negative effect on their work effort. This means that the more the teachers perceived politics in their school environments, the less likely they were to put in more efforts. Thus, perception of politics can or may be a distraction at the workplace and may affect work efforts. Karmar et al. (2009) indicated that politics perception affects individuals' self-evaluation and they perform best at workplaces that are less threatening. Similarly, Bodla et al. (2014) found that perceptions of workplace politics affected employees' performance. In addition, heightened workplace politics can undermine perceptions of justice in reward allocations, and trigger several apathetic (motivating) outcomes related to uncertainty or clarity (Kapoutsis, Papalexandris, Nikolopoulos, Hochwarter \& Ferris, 2011). When people perceive unfair treatment at the workplace, they may reciprocate the perceived unfair treatment with reduced work efforts. This invariably would affect the energy that individuals put into their work to achieve the desired results.

The results in the current study also indicated that perception of politics in the school environment had a positive relationship with psychological safety. This was an unexpected finding, as it was projected that the perception of unjust and unfair treatment in the work environment would have resulted in mistrust and disharmony among the teachers. When the dimensions of politics perception were partitioned, the results showed that only general political behaviour is significantly related to psychological safety. General political behaviour involves behaving in ways that support 
individuals that are perceived to possess something of value in order to receive favors from them. This therefore could explain why the perception of politics is positively related with psychological safety perception.

It is important to note also that there have been mixed findings regarding the effects of perception of organizational politics (Cropanzano, Howes, Grandey \& Toth, as cited in Bodla, et al., 2014). Some studies suggest that organizational politics create opportunities for individuals with political skills (Hochwarter et al., 2003). Vigoda (2002) posits that perception of politics at the workplace may be beneficial to individuals in terms of career advancement, recognition and status, and enhanced sense of control. Thus, individuals with political skills may be able to leverage on the political environment to their advantage. In such situations, perceptions of politics may engender a feeling of psychological safety. When there is high political support from supervisors, employees are able to cope with the political environment more effectively (Kane-Frieder, Hochwarter, Hampton \& Ferris, 2014).

Kane-Frieder et al. (2014) suggest that co-existence of perception of politics and supervisor political support results in exchange relationship in which each party has some expectation of the other. Thus, this reduces the negative effect of the political environment. Another important point for consideration was the findings by Drory and Romm (1988) and Drory (1993). The findings of these studies suggest that the effect of perception of politics depends on the status of the individual involved. They suggest that high status individuals are less likely to be affected negatively by high workplace political environment than low status employees. This is because the high status individuals are in better position to shape and benefit from decision-making processes. It is worthy to note that only general political behaviour is significantly related positively with psychological safety perception. Given the category of teachers used in this study, and the fact that most of them are likely to be involved and influenced in the decision-making processes in their schools, this could explain why perception of politics had a positive relationship with perception of psychological safety.

Psychological safety has been posited to influence involvement in continuous quality improvement efforts (Nembhard \& Edmondson, 2006) as well as job engagement (Rathert, Ishqaidef \& May, 2009; Vogelgesang, 2008). The findings of the current study also support the findings of Kruzich at al. and Bodla et al. Psychological safety has been found to be a mechanism for organizational learning (Edmonson, 2004). Edmonson notes that specific leader behaviors, such as being available and accessible, inviting input, and modelling openness and fallibility, directly shape followers' perceptions of psychological safety (Edmondson, 2004). When leaders display a high level of openness to inputs from members and make themselves accessible and 
available to them both physically and psychologically, the members may develop a sense that it is psychologically safe to express and share their thoughts.

Meanwhile, there was no relationship between psychological safety perception work efforts. This finding was unexpected. Studies indicate that feelings of low psychological safety make workers less likely to voice their concerns and share their ideas in ways that facilitate learning from failures and taking initiatives (Hirak, Peng, Carmeli \& Schaubroeck, 2012). Hirak et al. noted that the low propensity to take initiatives and be innovative results in more failures in the future and even poorer work efforts and performance, while high perception of psychological safety makes employees develop more fully and have shared understandings of tasks and problems.

\subsection{Conclusions and Implications for Practice and Research}

The findings from the current study suggest that perception of workplace politics is a critical determinant of attitude and behaviour of individuals at work. It confirms the suggestion that perceptions are critical in shaping the attitudes and actions of individuals in various settings. When people perceive unfair treatment at the workplace, they may reciprocate by withholding vital information and work effort. This implies that management of schools and other workplaces must endeavor to ensure fairness in their relationships with their subordinates. Employees should be encouraged to relate with each other with utmost good faith. Efforts must be made to promote interpersonal trust among employees, and also between employees and management.

The positive relationship between perception of organizational politics and psychological safety perceptions, and the lack of significant relationship between psychological safety and work effort, suggest that there is the need for more studies to be conducted to help in the understanding of the effect of perception of politics on work outcomes and attitudes. The effects of perception of organizational politics on work behaviour, attitudes, and outcomes are really complex and require more studies to investigate the nature of these relationships. Also, the lack of relationship between psychological safety and work effort suggests that perception of organizational politics and psychological safety are distinct constructs. The fact that perception of politics is related strongly to work efforts than psychological safety also suggests that perception of politics could be a mediator in many situations as in Vigoda's (2007) leader in-role behaviour and organizational citizenship behaviour study. Research efforts must be made to investigate antecedents of perception of organizational politics, as well as investigating other moderating variables. 


\subsection{Limitations of the Study}

The major limitation of the study stems from the convenience sampling procedure that was used to select the respondents as it was not possible to use random sampling procedure. This may mean that the data may not accurately represent the population. For this reason, the adjusted regression coefficients were reported. The self-report measure of work effort is another area that might affect the validity of the data for the study. In self-report measures, people generally respond in ways that are socially desirable. However, given the assurance to the respondents that the data was going to be processed in aggregate and that no individual responses would be identified, this paper is of the view that the responses largely reflected the true perceptions of the respondents.

\section{References:}

1. Anderson, D. B. (1994). Performance appraisal: A different approach. FBI L. Enforcement Bulletin, 63, 18.

2. Akinyemi, A. (1993). Job satisfaction among teachers in Ondo State Secondary School. Journal of Educational Leadership, 29(4), 10-22.

3. Ashford, S. J. \& Tsui, A. S. (1991). Self-regulation for managerial effectiveness: The role of active feedback seeking. Academy of Management Journal, 34(2), 251-280.

4. Bodla, M. A., Afza, T., \& Danish, R. Q. (2014). Relationship between organizational politics perceptions and employees' performance; mediating role of social exchange perceptions. Pakinstan Journal of Commerce and Social Science, 8(2), 426-444.

5. Bodla, M.A. \& Danish, R. Q. (2009). Politics and Workplace: An empirical examination of the relationship between perceived organizational politics and work performance. South Asian Journal of Management, 16(1), 44-62.

6. Brandon, R. \& Seldman, M. (2004). Survival of the savvy: Highintegrity political tactics forded career and company success. New York: Free Press.

7. Bresman, H. \& Zellmer-Bruhn, M. (2013). The structural context of team learning: effects of organizational and team structure on internal and external learning. Organization Science, 24(4), 1120-1139.

8. Cropanzano, R., Howes, J. C., Grandey, A. A., \& Toth, P. (1997). The relationship of organizational politics and support to work behaviors, attitudes, and stress. Journal of Organizational Behavior, 18(2), 159180.

9. De Cooman, R., De Gieter, S., Pepermans, R., Jegers, M., \& Van Acker, F. (2009). Development and validation of the work effort scale. European Journal of Psychological Assessment, 25(4), 266-274. 
10. Dhar, R. L. (2009). Cynicism in the Indian IT Organizations: An Exploration of the Employees' Perspectives. Qualitative Sociology Review, 5(1), 152-175

11. Drory, A. \& Romm, T. (1988). What organizational politics is: organization members, perceptions? Organization Studies, 9(2), 165179.

12. Drory, A. (1993). Perceived political climate and job attitudes. Organization Studies, 14(1), 59-71.

13. DuBRJN, A. J. (1991). Sex and gender differences in tactics of influence. Psychological Reports, 68(2), 635-646.

14. Edmondson, A. (2003). Psychological safety, trust, and learning in organizations: a group-level lens. Retrieved on December 5, 2017 from ttp://citeseerx.ist.psu.edu/viewdoc/download?doi=10.1.1.195.4023\&r ep=rep1\&type $=$ pdf.

15. Edmondson, A. C. (2004). Psychological safety, trust, and learning in organizations: A group-level lens. In R. M. Kramer, K. S. Cook (Eds), Trust and Distrust in Organizations: Dilemmas and Approaches, pp. 239-72. New York: Russell Sage.

16. Edmondson, A.C. \& Woolley, A. W. (2003). Understanding outcomes of organizational learning interventions. In M. Easterby-Smith \& M. Lyles (Eds), International Handbook on Organizational Learning and Knowledge Management. London: Blackwell.

17. Ferris, G. R., Harrell-Cook, G., \& Dulebohn, J. H. (2000). Organizational politics: The nature of the relationship between politics perceptions and political behaviour. Research in the Sociology of Organizations, 17, 89-130.

18. Ferris, G. R., Hochwarter, W. A., Douglas, C., Blass, F. R., Kolodinsky, R. W., \& Treadway, D. C. (2002). Social influence processes in organizations and human resources systems. Research in Personnel and Human Resources Management, 21, 65-127.

19. Ferris, G. R., Russ, G. S., \& Fandt, P. M. (1989). Politics in organizations. Impression Management in the Organization, 143(170), 79-100.

20. Ferris, G. R., Adams, G., Kolodinsky, R.W., Hochwarter, W.A., \& Ammeter, A.P. (2002). Perceptions of organizational politics: Theory and research directions. In F. Dansereau \& F. J. Yammarino (Eds.), Research in Multi-Level Issues, 1. Oxford, UK: Elsevier Science/JAI Press.

21. Folger, R., Konovsky, M.A., \& Cropanzano, R. (1992). A due process metaphor for performance appraisal. Research in Organizational Behaviour, 14, 129-177. 
22. Gallagher, V. G. \& Laird, M. D. (2008). The interaction of political skill and political decision making on job satisfaction. Journal of Applied Social Psychology, 38, 2336-2360.

23. Gandz, J. \& Murray, V.V. (1980). The experience of workplace politics. Academy of Management Journal, 23(2), 237 - 251.

24. George, J. \& James, L. (1993) Personality, affect, and behaviour in groups revisited: Comment on aggregation, levels of analysis, and a recent application of within and between analyses. Journal of Applied Psychology, 78, 789-804.

25. Hirak, R., Peng, A. C., Carmeli, A., \& Schaubroeck, J. M. (2012). Linking leader inclusiveness to work unit performance: The importance of psychological safety and learning from failures. The Leadership Quarterly 23, 107-117.

26. Hochwarter, W., Kacmar, C., Perrewé, P., \& Johnson, D. (2003). Perceived organizational support as a mediator of the relationship between politics perceptions and work outcomes. Journal of Vocational Behavior, 63, 438-465.

27. Kacmar, K.M. \& Baron, R.A. (1999). Organizational politics: The state of the field links to related processes, and an agenda for future research. In G. R. Ferris (Ed.), Research in Personnel and Human Resources Management. Greenwich, CT: Jai Press.

28. Kacmar, K.M. \& Ferris, G.R. (1991). Perceptions of organizational politics scale (POPS): Development and construct validation. Educational and Psychological Measurement, 51(1), 193-205.

29. Kacmar, K. M., Bozeman, D. P., Carlson, D. S., \& Anthony, W. P. (1999). An examination of the perceptions of organizational politics model: Replication and extension. Human Relations, 52(3), 383-416.

30. Kacmar, K., Collins, B., Harris, K., \& Judge, T. (2009). Core selfevaluations and job performance: The role of the perceived work environment. The Journal of Applied Psychology, 94, 1572-1580.

31. Kahn, W.A. (1990). Psychological conditions of personal engagement and disengagement at work. Academy of Management Journal, 33(4), 692-724.

32. Kane-Frieder, R.E., Hochwarter, W. A., Hampton, H. L., \& Ferris, G. R. (2014). Supervisor political support as a buffer to subordinates' reactions to politics perceptions: a three-sample investigation. Career Development International, 19(1), 27-48.

33. Kapoutsis, I., Papalexandris, A., Nikolopoulos, A., Hochwarter, W. A., \& Ferris, G. R. (2011). Politics perceptions as moderator of the political skill - job performance relationship: A two-study, crossnational, constructive replication. Journal of Vocational Behaviour, $78,123-135$. 
34. Kruzich, J. M., Mienko, J. A., \& Courtney, M. E. (2014). Individual and work group influences on turnover intention among public child welfare workers: The effects of work group psychological safety. Children and Youth Services Review, 42, 20-27.

35. Lencioni, P.M. (2006). Silos, politics and turf wars: A leadership fable about destroying the barriers that turn colleagues into competitors. New York: Jossey-Bass.

36. Lewin, K. (1936). Principles of topological psychology; ingratiatory behaviors in organizational settings. Academy of Management Review, $13,572-587$.

37. Madison, D. L., Allen, R. W., Porter, L. W., Renwick, P. A., \& Mayes, B. T. (1980). Organizational politics: An exploration of managers' perceptions. Human Relations, 33(2), 79 - 100.

38. Maslyn, J. M. \& Fedor, D. B. (1998). Perceptions of politics: Does measuring different foci matter? Journal of Applied Psychology, 83(4), 645.

39. Nembhard, I.M. \& Edmondson, A.C. (2006). Making it safe: The effects of leader inclusiveness and professional status on psychological safety and improvement efforts in health care teams. Journal of Organizational Behaviour, 27, 941-966.

40. Ogungbamila, B. (2013). Occupational burnout among employees in some service occupations in Nigeria: Are health workers different? Psychological Thought, 6(1), 153-165. http://dx.doi.org/10.5964/psyct.v6i1.47

41. Okeniyi, C.M. (1995). Relationship between leadership problems and school performance in Oyo State secondary schools. Unpublished M. Ed. Thesis, University of Ibadan.

42. Poon, J.M. (2003). Situational antecedents and outcomes of organizational politics perceptions. Journal of Managerial Psychology, 18(2), 138-155.

43. Poon, J.M. (2006). Trust-in-supervisor and helping coworkers: moderating effect of perceived politics. Journal of Managerial Psychology, 21(6), 518-532.

44. Porter, L.W. (1976). Organizations as political animals. Presidential address, Division of Industrial Organizational Psychology, American Psychological Association 84th Annual Meeting, Washington, D. C.

45. Porter, L.W., Allen, R.W., \& Angle, H.L. (1983). The politics of upward influence in organizations. Organizational Influence Processes, 40(2), 408-422.

46. Rathert, C., Ishqaidef, G., \& May, D. R. (2009). Improving work environments in health care: Test of a theoretical framework. Health Care Management Review, 34, 334-343. 
47. Rosen, C. C., Levy, P. E., \& Hall, R. J. (2006). Placing perceptions of politics in the context of the feedback environment, employee attitudes, and job performance, Journal of Applied Psychology, 91(1), 211.

48. Schein, E. (1985). Organizational culture and leadership. San Francisco: Jossey-Bass.

49. Schön, D. (1983). The Reflective Practitioner. New York: Basic Books.

50. Vantilborgh, T., Bidee, J., Pepermans, R., Willems, J., Huybrechts, G., \& Jegers, M. (2014). Effects of ideological and relational psychological contract breach and fulfilment on volunteers' work effort. European Journal of Work and Organizational Psychology, 23(2), 217-230. DOI: 10.1080/1359432X.2012.740170

51. Vigoda, E. (2000). Internal politics in public administration systems. An empirical examination of its relationship with job congruence, organizational citizenship behaviour, and in role performance. Public Personnel Management, 29(2), 185 - 210.

52. Vigoda E. (2002). Reactions to organisational politics: Across-cultural examination in Israel and Britain. Human Relations Journal, 54, 14831518

53. Vigoda-Gadot, E. (2007). Leadership style, organizational politics, and employees' performance: An empirical examination of two competing models. Personnel Review, 36(5), 661-683.

54. Vogelgesang, G. R. (2008). How leader interactional transparency can impact follower psychological safety and role engagement. Paper AAI3291604. ETD collection for University of Nebraska. 